\title{
Megaregions imaginaries: excursions through a dialectical maze
}

Article

Accepted Version

Pain, K. (2017) Megaregions imaginaries: excursions through a dialectical maze. The Geographical Review, 107 (3). pp. 536-550. ISSN 1931-0846 doi: https://doi.org/10.1111/j.19310846.2016.12171.x Available at https://centaur.reading.ac.uk/46415/

It is advisable to refer to the publisher's version if you intend to cite from the work. See Guidance on citing.

To link to this article DOI: http://dx.doi.org/10.1111/j.1931-0846.2016.12171.x Publisher: Wiley

All outputs in CentAUR are protected by Intellectual Property Rights law, including copyright law. Copyright and IPR is retained by the creators or other copyright holders. Terms and conditions for use of this material are defined in the End User Agreement.

\section{www.reading.ac.uk/centaur}

\section{CentAUR}

Central Archive at the University of Reading

Reading's research outputs online 
GEOGRAPHICAL REVIEW ESSAY

MEGAREGIONS IMAGINARIES: EXCURSIONS

THROUGH A DIALECTICAL MAZE

KATHY PAIN

MEGAREGIONS: Globalization's New Urban Form? Edited by JOHN HARRISON and MiCHAEL HOYLER, xi and 270 pp.; diagrs., tables, index. Cheltenham, U.K.: Edward Elgar, 2015. \$130.00, (cloth). ISBN 9781782547891.

From the multiplicity of terminologies used to describe the emerging functional scales and composition of the world's twentyfirst-century urban landscapes, John Harrison and Michael Hoyler have taken a prominent U.S. term as the title for their edited volume of essays, Megaregions. This decision goes a long way in explaining their mission: to debunk "megaregions" "can-do," "hype" and "hysteria," recently popularised by American cult urban writers.

Yet, as the book's contributing authors frequently point out, the contemporary "imagined" megaregion (p. 17), or geographic "imaginary" (p. 120), has in reality been in emergence for decades, dating back to the early twentieth-century ideas of Patrick Geddes and their later U.S. reworking by Lewis Mumford, Jean Gottman, and others. Representations of urbanization processes even back then, highlighted the growth of the world's major cities as not 
simply a question of increasing size but of global constitution (Pain 2015a). However Harrison and Hoyler stress at the outset that the reader should heed August Hecksher's warning of fifty years ago that an awe-inspiring spatial concept can allow dangerous "misconceptions" to take root (p. 1). They reapply Hecksher's prophetic anxiety about the dramatic power of Gottman's midtwentieth-century "megalopolis"---heralded as a new stage in human civilization---to the "megaregion" (p. 4).

In line with Gottman's prediction that the interwoven urban formation of 25 million population on the U.S. Northeastern seaboard was the beginning of a new American urban demographic, a rash of twenty-first-century megaregions expected to represent more than 70 percent of the nation's population growth by 2050 , has now been identified by independent research and planning organisation, the U.S. Regional Plan Association (RPA) (2006a, 4). According to Harrison and Hoyler, all the excitement whipped up by the populist narrative of new millennium "regional globalization" has led this iconic U.S.-style megaregion to become regarded as the globally competitive urban form of the future (Ohmae 1999; Porter 2001; Scott 2001; Florida, Gulden, and Mellander 2008; Short 2010).

The starting premise for the book, then, is that the power of the megaregion as the symbol of economic competitiveness has triggered an international epidemic of megaregion imaginings, 
reflecting a naïve assumption that this new phenomenon can be easily delineated and so used to territorial advantage. Its editors are well equipped to provide an innovative addition to the literature on this subject, combining Harrison's theoretical fluency in debate on the meaning and existence of the region and Hoyler's hands-on experience of European urban and regional empirical analysis. Critical insights into territorial rescaling introduced to geopolitical discourse by Neil Brenner are drawn on to inform a distinctive mission for the volume: to shed light on the construction of the megaregion, academically and politically (Brenner 1998a, b, 1999; Brenner 2004, 2009). Organised in ten chapters, one of the book's central purposes is digging deep to unearth and expose the megaregion as a fuzzy concept, too simplistically defined and researched, invoked as a competitive device in the U.S. and beyond.

$$
<<\text { A-HEAD }>>\text { FRAILTIES-THE VOLUME }
$$

As indicated by the book's title, the bold popular assertion for critical analysis in the volume is that the megaregion constitutes "globalization's new urban form". We are told: "What marks megaregions out from other spatial concepts presently is that for the first time in history the megaregion has become a truly global concept" (p. 14). But, unravelling the significance of the 
megaregion as a spatial imaginary beyond its U.S. academic and geopolitical framing is, not surprisingly, not straightforward.

In the introductory chapter, Harrison and Hoyler present a useful typology of common concepts and analytical approaches (seen as megaregion "variants," pp. 8--10) followed by brief discussion of some basic distinctions, commonalities, and deficiencies. Setting analytical parameters was understood to be important "because it ensures that as researchers we begin with the same objects under our consideration" (p. 237). Contributing authors were expected to consider, first, how robust are the foundations of megaregion conceptual construction; second, the methodological challenges of researching megaregions; and, third, whether megaregions really are globalization's new urban form and, if not, whether there are "more suitable" spatial frameworks (p. 22). The intention is to advance critical analysis beyond consideration of "the what and where," to "the who, the how and the why" of megaregions (pp. 22--23). Nonetheless, the difficulty of providing a comparative analytic dimension beyond the introduction in an edited volume is plainly evident.

Harrison and Hoyler draw out some key threads emerging from the collection in their conclusion; however, the detail of divergences between what seem, superficially, to be similar extant urban processes and territorial constructions presenting in different situations, is not covered systematically across the essays. An intellectual challenge for the reader is to establish the significance, 
or not, of potential theoretical and empirical specificities and nuances, important in rigorous analysis of a "chaotic concept" ( $p$. 4).

An obvious editorial challenge has clearly been posed by the decision to make just one spatial concept (mainly associated with one country) the focus of attention. As Harrison and Hoyler discuss in conclusion, "privileging megaregions over other spatial imaginaries...presents a compelling narrative that only tells part of the story" (p. 237) and this is especially problematic given the insistent editorial focus on "more critical analyses of megaregions, megaregionality and the megaregion concept" (p. 22). Although the problem is dealt with to an extent by reference to megaregionalism as a political strategy (which potentially has farreaching significance), the question to what extent alternative concepts and constructs are simply "megaregion variants," and to what extent they represent distinctive development and/or geopolitical processes ultimately proves hard to establish. Furthermore the megaregion is not simply a homegrown U.S. imaginary, so determining its real symbolic influence beyond the U.S. is selfevidently challenging.

Gottman's megalopolis introduced to the U.S. an interpretation of megaurbanisation as part of the solution to its social and economic problems, breaking away from antecedents that had highlighted it as a threat to civilization. But, as Harrison and Hoyler point out, the modern U.S. megaregion has also 
borrowed ideas from recent European spatial-planning thinking (Mehlbye 2000; Faludi 2002). And the travel of ideas, and their direction over time, between actors and places, is fundamentally important to understanding the positioning of spatial concepts and their academic and policy invocations---in other words, the who, the how, and the why of megaregions---as will be illustrated later. In consequence, unravelling the power of the megaregion as a globalization reality and/or narrative is essentially problematical. Megaregions presents an excellent collection of spatialimaginary cameos drawn from the U.S. and beyond, together with theoretically searching and provocative commentary from its editors. However, readers new to this field of regional analysis and discourse must be critically alert both methodologically and dialectically in traversing its varied attempts to pin down "the foundations, frailties and futures of megaregional research" (p. 4).

\section{$<<$ A-HEAD $>>$ THE MEGAREgIONS ESSAYS}

Markus Hesse, chapter 2, opens the conversation about "mega-" region conceptualisation at a theoretically high level by exploring its linked metaphorical and representational epistemologies. His fluent analysis draws attention to the significance of meganarratives, including the "globalization rationale," in the (unhelpful) construction of essentialist representations of space ( $\mathrm{p}$. 43). This essay usefully positions the megaregion in the 
longstanding spatial narrative that aligns competitiveness with size. Hesse's constructivist thinking provides a discursive theoretical context for the contributions that follow. The importance of "language, communication and discursive interaction" is highlighted (p. 39), but so too is the need "to be concerned with the materiality of real-world problems" (p. 43). Hesse's call for balanced attention to dialectical and material considerations is especially pertinent in light of the danger, later referred to in chapter 9 by Billy Fleming, that critical analysis may demote the importance of taking seriously research into new spaces for urban analysis.

A line of thinking not pursued here, however, is the possibility that understanding evolving relationships among urban imaginaries, political projects, and material real-world problems, may actually be assisted by reference to a particular globalization rationale, the rationale of qualitative "socio-technological transition" (Pain and Van Hamme 2014, 5). After all, Mumford's (antimega) dystopic vision of the very large city (p. 36) resonated with that of Ebenezer Howard, creator of the "social" or "garden city" multicenter urban vision. Yet this multicenter or "polycentric" imaginary was later to be used in economic boosterism strategies at diverse territorial scales. From the "Randstad" Netherlands project that began in 1958 (Lambregts 2006) to later Europe-wide promotion of the "polycentric urban region" (PUR) (Pain 2011a) and recent "cross- 
border" regional constellations (see chapter 7), the multicenter imaginary has, on the one hand, been subject to political manipulation in territorial rescaling strategies and, on the other hand, it has proved a less sustainable model than Howard could ever have predicted prior to mass automobile ownership in a globalizing society (Cochrane and Pain 2000; Halbert, Pain, and Thierstein 2006; Pain 2010, 2011a, 2015b). Evolving urban processes, communicative structures, and material realities are interactive over time hence attention to the local-global construction of space matters.

Following Hesse's lead, both David Wachsmuth and Alex Schafran similarly take a purposeful historical approach to evaluation and critique of the megaregion as overgeneralized conceptually.

Focusing on the U.S. in chapter 3 , Wachsmuth critically engages with U.S. policy discourse, highlighting megaregions as "strategic terrains in which a multitude of differently scaled competitiveness strategies are being enacted" (p. 52). He helpfully provides a detailed and reflective analysis of urbanized spaces as both internally and externally connected, "simultaneously both city and urban network" (pp. 51--52), a line of thinking that could have valuably been developed in Harrison and Hoyler's concluding chapter (p. 10). Importantly, he also questions the prevalent notion 
that megaregions have agency as competitive global economic actors. On the contrary, even when megaregions are strongly promoted, they are typically politically fragmented, contested spaces, as Stephen M. Wheeler later highlights. Furthermore, Wachsmuth draws attention to the critical relevance of understanding distinctions between different sources of megaregion functional connectivity (important also for Xu Zhang, chapter 8 ); for example, the connectivity generated primarily by manufacturing production and/or by advanced producer services. The essay has an important role in the book in attending to the megaregion as an imaginary that is simultaneously politically constructed and at the same time an outcome of active urban processes.

Schafran's essay in chapter 4 presents a polemical view of (presumed by Schafran) underhistoricized academic research that has fed the megaregion imaginary and it's (assumed by Schafran) variants (p. 75). One example, the 2003--06 "Polynet: Sustainable Management of European Polycentric Mega-City Regions" study (briefly introduced by Harrison and Hoyler, pp. 16--17) is singled out for particular scrutiny (Hall and Pain 2006).

Led by the late Sir Peter Hall and myself in the U.K., this research investigated the aforementioned multicenter PUR imaginary in Northwest Europe from a novel functional perspective that 
incorporated "Globalization and World Cities Network" (GaWC) "world city network analysis" pioneered by Peter Taylor (Taylor 2004; Pain and Hall 2008). By exploring, quantitatively and qualitatively, multiscale business, informational and travel networks and flows that are interconnecting towns and cities both physically and virtually in "mega-city region" spaces, Polynet shed light for the first time on the PUR as characterised by distinctive morphological and functional processes. But, regrettably, Schafran does not refer to the range of work reported on by the international research team, which includes important findings on PUR uneven geographies and differences, and their policy implications. He therefore expresses surprise to have discovered that "in one of the many ironies of megaregional research, it is from a generally ignored piece by two of global cities theory's greatest protagonists" (p. 76), Taylor and myself, that an insightful process analysis of the Polynet results has emerged (Taylor and Pain 2007). Schafran seems to assume that the analysis appeared by magic from a "hail of numbers, rankings and schematic maps" that overshadows "what is happening on the ground" (p. 78).

Nevertheless, three case studies are introduced to illustrate the piece's "practical use in advancing mega-regional research" (p. 78). A number of Polynet insights reemerge here; for example, megaregions "should be defined in part by the fact that their urban networks exceed any attempts to unify them politically and likely 
always will" (p. 86), and as "a functional process inseparable from historicized urbanization" (p. 90)---Schafran's assumption that Polynet was underhistoricized is misplaced.

According to Schafran, Ludovic Halbert's Paris analysis for example, does not, but should, combine "political-historical and economic analysis" (p. 81). However, this criticism seems unduly harsh given that Halbert explores political influences on the development of the Paris region since the publication of JeanFrançois Gravier's Paris et le desert français (1947, cited by Halbert 2006, 189) and also makes reference to work by Frederic Gilli $(2006,184)$ that is highly commended by Schafran (p. 81). It can only be assumed that Schafran has not studied Halbert's research in detail, in particular his 2006 paper entitled "The Polycentric City Region That Never Was." It is not so surprising that they agree that Paris "is not truly polycentric and likely never will be" (p. 83), since the process framework that Schafran employs in his "The Island of France" example was identified by the Polynet research, and Halbert's contribution to it. Taylor and Pain's (2007) analysis did not appear by magic in the "wide-eyed hysteria" engendered by globalization that Schafran refers to (p. 75) after all!

Wheeler's essay, chapter 5 , is an unexpected contribution to this book in that it looks back to the "deep green" environmentalist 
perspective of the 1970s. Rare within this volume is positive reference to some big urban regions, including London (p. 99). On the other hand, the interrelationships between such agglomerations, the regional globalization process, and "local and sustainable communities" required carefully considered fleshing out (p. 97). For example, Wheeler proposes a need for "growth management" (p. 99) for which "greenbelt" and reduced commuting strategies are prescribed (p. 114). But, as the Polynet research revealed, urban-containment policies for London and the Randstad, Netherlands---both referred to by Wheeler as regional growth management successes---have proved unable to halt the emergence of functionally interconnected urbanized spaces extending far beyond their metropolitan boundaries with high dependency on environmentally unsustainable travel by car (Pain 2015b). Vibrant "Jacobsian" urban growth processes can leap over urban green belts as they do Japanese mountains (Taylor and Pain 2007).

Unusually within this volume, the essays engage directly with realworld material and (fractured) planning, and governance dilemmas (100 onwards); however, there is a danger of oversimplifying urban processes by proposing uncontextualized policy prescriptions (see p. 114). "One size fits all” planning solutions imply the existence of a generalized regionalization process independent of local historical and geopolitical contexts. Clearly, nuanced processes require nuanced responses. 
The final four essays reflect their authors' experience of immersion in empirical regional analysis, adding an important research practice dimension to the collection. In chapter 6, Michael R. Glass takes the focus on governance forward beyond Wheeler's emphasis on policy strategies. In contrast, he highlights that "there is no capacity to enact a new regional governance framework---at any scale---detached from the inherited and often overlapping political, social, and economic geographies of those spaces" (p. 120). Geographic exigencies (changing geographic patterns and spatial dynamism) run alongside political exigencies (interregional competition and spatial rescaling). According to Glass, together, these exigencies preclude the development of the megaregion scale as a governable reality, as illustrated in his overview of regional government and governance in western Pennsylvania and the Great Lakes area of the U.S.

Next, the issue of scale is approached in a European context by Lukas Smas and Peter Schmitt, who present the case of the construction of "Norden," a specifically cross-border regional imaginary supported by European policy (pp. 158--159). An emergent Baltic Sea macroregion presents further exemplification of ways in which soft, networked space is being "bordered" in line with national and European political agendas. This essay is strong and empirically informed; at the same time, it engages with 
theoretically important questions first raised by Brenner about the role of policy framing in the invention of rescaled megaregion spaces intended to enhance Europe's global competitiveness (Brenner 1999; Brenner and Theodore 2002).

Zhang's China example is a similarly unpretentious account of the state of research in the case of the Pearl River Delta. The essay provides a useful contrast to the U.S. and European contexts, illustrating the importance of research in uncovering nuanced megaregion processes and dynamics. It both depicts Chinese urban regionalisation as a historically and politically shaped process and urges that distinctions among specific situations be subject to rigorous empirical investigation to inform responses to real development challenges in rapidly urbanising countries like China.

Finally, back to the U.S., Fleming's essay in also stands out as empirically well-informed. Importantly, this essay enriches a space for contemplation that is underattended elsewhere in the book by reflecting on interviews with real-world megaregion actors, as opposed to simply assuming their motivations for engagement with this interurban functional scale. Fleming calls for research, rather than just critical commentary, to inform urban-process understanding, thus delivering an important message to take from the book. 
Harrison and Hoyler's concluding chapter endeavours to draw together thinking from across the volume. The reader is reminded of the book's intended focus on the who, how and why of megaregions, in short, on questions of "agency," "process," and "specific interests" (p. 230). However, the bold editorial decision to single out one spatial concept for attention and critique---the megaregion---inevitably conditions the lines of discussion: this "compelling narrative ... only tells part of the story" (p. 237).

U.S. Cali Baja, Hampton Roads-Richmond (pp. 231--234), and European PAR-LON (pp. 234--236) are introduced as examples of recent political projects invoking new megaregional frames for territorial rescaling. But the Paris-London, PAR-LON, imaginary, speculated here to be a new political "space of engagement," serves to illustrate the importance of Harrison and Hoyler's final reminder at the close of the book that a powerful imaginary must be treated carefully (p. 251). PAR-LON is not so new and is not such an empty French territorial political fabrication as is suggested (p. 235). The "megaregions-critique" lens employed here tells only part of the story.

Citing an open letter in 2014 from Paris Deputy Mayor, Anne Hidalgo, to Boris Johnson, London's Mayor, PAR-LON is 
proposed by Harrison and Hoyler as an imaginary that is representative of Paris "reaching out to London, much like Cali Baja is reaching out to San Diego and Los Angeles" (p. 235). But the PAR-LON concept was originally introduced in a GaWC research paper (not cited by Harrison and Hoyler) written five years before the date of Hidalgo's letter (Halbert and Pain 2009).

PAR-LON is represented as a "further example of endeavours to politically construct a megaregional space of engagement in order to secure certain economic interests from external threats which seek to undermine or dissolve them" (p. 235). However, Halbert and Pain's conceptualization, which drew on Polynet analysis, on the contrary, reflected a deterritorialised understanding of ParisLondon relations as real and actual functionally networked "flowplaces," or "an operational implementation of Castells "spaces of flows" at the "intra-metropolitan level" (Castells 1996):

“...the daily practices of people, firms, and even institutions, which connect places into a geography of flows ... knowledge is produced in but also flows through PAR-LON, reflecting complementary functional world city network relations." (Halbert and Pain 2009, 15)

Halbert and Pain's PAR-LON is indicative of actual Paris-London relations that lend credence to Hidalgo's claim, demonstrating how 
susceptible a concept is to uncertain meanings, intentions, and interpretations. This leads to three important analytical observations.

First, as Harrison and Hoyler observe in reflecting back on the volume, "Megaregions always need to be considered within the broader contours of global urban studies" (p. 238). They admit that, "Put simply, in producing this book it has become clearer to us that focusing on one spatial unit or imaginary provides an ever deceasing lens on the totality of our globalizing urban world." (pp. 238--239)

As noted earlier by Wachsmuth, megaregion analysis needs to include complex interscale urban and social-network relations under revision and reconstruction. Awareness of connectivities beyond "static attributes, such as the location of activities" in Polynet, is critically important in understanding the stretching of contemporary urban relations in softening, networked spaces, including the process of regional globalization (Halbert and Pain 2009, 15; Pain 2011a, b).

Second, PAR-LON illustrates the importance of Harrison and Hoyler's focus in the book on the who, the how and the why of the megaregion. Appropriate searching questions are raised in relation to PAR-LON, for example, "why London," "why now" (p. 236)? 
But establishing meaningful answers to such questions requires a semiotic approach to analysis that takes into account evolving communicative contexts: "megaregions mean different things, to different people, in different contexts" (p. 237).

Finally, it is not known whether Hidalgo was personally aware of and influenced by Polynet findings on Paris-London relations when she wrote her letter to Johnson. However, this is very possible given the number of research publications and presentations to French academic, policy, and practitioner audiences on this subject (for example, Halbert, Pain, and Taylor 2007; Pain 2009; Halbert and Pain 2010; Pain 2011b). So Hidalgo's Paris-London imaginary may not just “be the vehicle for communicating a particular story to its chosen audience" as inferred by Harrison and Hoyler (pp. 235--236), instead it may really be part of the story. Was Hidalgo's "courting of Johnson and London" a genuine attempt to plan and govern in a manner that reflects PAR-LON functional relations? The point is that we cannot say. Questions about "agency," "process," and "specific interests" (p. 230) in spatial-imaginary construction are contextdependent and call for a semiotic approach in analysis. Focusing on the exemplification of megaregions geopolitical semantics in critical analysis tells a partial story. These same analytical observations are further emphasised in a U.S. context. 
In chapter 1, the U.S. megaregion is introduced by Harrison and Hoyler as emanating from a form-focused analytical approach that has an "unwitting tendency ... to infer and/or assume the functional coherence of the megaregional spaces they identify" ( $p$. 15). Further, U.S. Department of Transportation (DoT) funding to megaregions research is discussed as having encouraged a focus that is "almost exclusively on issues of transportation" (p. 20; footnote 8 , p. 23):

"It is no secret that much of the support for work on the megaregion concept came from the US Department of Transportation, for whom the megaregion is a vehicle through which they can raise the profile of what they see as the benefits of high-speed rail for economic development.” (p. 20)

Drawing on the personal experience of this author of interactions with the RPA (Regional Plan Association) “America 2050" megaregions campaign process since 2004 as codirector of the Polynet study, introduces other potential dimensions to Harrison and Hoyler's megaregions construction story. As Fleming illustrates, megaregional planning research and pedagogy are complex. 
For instance, research conducted by RPA "National Committee for America 2050" member, Robert E. Lang, "From Megalopolis to Megapolitan: Framework for Planning Transmetropolitan Development in the US," incorporated GaWC worldwide citynetwork analysis also used in Polynet, which was by then underway (Taylor 2004; Taylor and Lang 2004; Taylor, Evans, and Pain 2006). Supported by U.S. Lincoln Foundation funding, Lang's 2004 project introduced a new approach to academic debate on U.S. metropolitan regionalism. Transmetropolitan clusters were studied as functionally and spatially connected "Megapolitan" spaces defined by intercity "place-flow" relations as opposed to form-focused morphological relations (Lang and Taylor 2005). And this functional "megaregions variant" was undoubtedly influential in RPA thinking (Todorovich 2007a, b; Regional Plan Association 2008). After all, the research results were to be shared with RPA research partners at the University of Pennsylvania "Super City" researchers and the Lincoln Institute of Land Policy. "Functional coherence of the megaregional spaces" should therefore not be represented simply as inferred and/or assumed by the "'North American' school of megaregionalists" (p. 15). The “"European School’ of megaregionalists...function-dominated approach" has undoubtedly had a presence in U.S. megaregions debate. This author was certainly active in communicating Polynet methods and results, and their implications for the U.S., at intensive RPA and Lincoln Institute organised research events in 
Vienna, Austria, and Healdsburg, California, where the Taylor and Pain paper was presented (2007).

The findings from both Polynet and Lang's research emphasized the problem of environmentally unsustainable commuting by automobile posed by the transmetropolitan growth process, and therefore the need for strategic planning (see Lang and Dhavale, 2005a, b). Lang proposed that federal aid in areas such as transportation could be tied to functional megapolitan, instead of metropolitan, planning. His ambitious ultimate goal was "...for the US Census Bureau to formally adopt a Megapolitan designation. In doing so, Census would confer legitimacy onto Megapolitan areas that would help these places start planning." (http://www.lboro.ac.uk/gawc/projects/projec44.html)

It could be speculated, first, that contrary to Harrison and Hoyler's conjecture that U.S. DoT research funding played a major part in shaping the "America 2050" agenda, the focus on transportation issues was sharpened by the megapolitans and Polynet functional research findings (Carbonell and Yaro 2005). Second, it could be speculated also that the megapolitan and Polynet emphasis on the need for megaplanning contributed to a megaregions focus on issues of form and size. 
As Harrison and Hoyler (p. 21) and Fleming (p. 212) note, Lang had referred to the U.S. Census Bureau's Combined Statistical Areas (CSAs) and population data to inform the megapolitans' "place" component. Daily-commuting data were used to illustrate the physical extent of European megacity region formations in Polynet. Or, on the other hand, there may have simply been a failure to appreciate the relevance of complex interscale citynetwork relations under revision and reconstruction for the U.S. situation. A 2009 review of the megaregions methodology by RPA staff member, Yoav Hagler, suggests that this too could be part of the megaregions construction story (Hagler 2009).

In his review, Hagler proposed that adding to existing population and employment analyses already used by researchers in defining megaregions, data on intercity passenger travel, and freight movement, would "move toward answering many of the unanswered questions on connectivity that were not answered in the RPA process" (2009, p. 6, p. 8). However, he claimed citynetwork relations to be unrepresentative of local physical U.S. realities, thereby (arguably) diverting attention away from the U.S. megaregion as a globally networked functional reality:

"The method employed by Taylor and Lang (2005) of business flow analysis as a measure of how cities are connected could greatly enhance the understanding of the megaregions. This method 
however, also has significant drawbacks in this context... This analysis is appropriate to assess the international flow of intellectual capital but does little to address the particular spatial challenges that face the megaregions." (p. 8)

How significant was Hagler's report in influencing subsequent megaregions methodological decision making? As in the case of influences and motivations in the PAR-LON example, we cannot say. What this brief reflection on the evolution of megaregions construction does illustrate, however, is just how fuzzy and messy the story can be. In consequence, an analytical focus on geopolitical semantics can all too easily skip over aspects of the story that are highly pertinent to questions of agency, process, and specific interests. Qualitative research by Fleming---also undertaken with business, policy, and practitioner actors in the Polynet study---demonstrates the value of including megaregional actors in the conversation about these questions.

This author's interaction with the U.S. megaregions project since 2004 endorses Fleming's findings on the evolutionary and multifaceted nature of U.S. megaregional research and planning construction (p. 201). It has also suggested that the RPA mission has been founded on real concern for the promotion of a more sustainable U.S. urban development pattern (see also Pushkarev 1969, cited by Todorovich 2007b, 10; Lincoln Institute of Land 
Policy, Regional Plan Association and University of Pennsylvania School of Design 2004). Issues that were the focus of attention in 2004 were U.S. population growth, social and economic disparities within and between American regions, overcrowded and deteriorating infrastructures, and climate change mitigation (RPA 2006a; Todorovich 2011, 263). Past research by Lang has equally been concerned with issues of equity, including affordable housing and gated communities. In other words, megaregional research interests in the U.S., and in Europe, do go beyond a focus on "the wealthy, the powerful, or the creative" functional networks, a "narrow geo-economic logic" and the "partial explanation of the phenomena of megaregionality" discussed by Schafran (p. 78). Fleming notes the diverse thematic areas that U.S. megaregional actors are now engaging with (p. 214), including a deeper ecological perspective (p. 223).

That is not to say that economic growth, and U.S. global competitiveness, have not been prioritised alongside sustainable transportation and planning (Sassen 2007; Lang and Nelson 2007, 2009). Under the influence of inputs from European spatial planners espousing the merits of the polycentric urban form, there has been an assumption that, with judicious European-style planning, economic growth, social cohesion, and environmentally sustainable development can go hand-in-hand with metropolitan regionalisation (Regional Plan Association 2006a, 14, 2006b; 
Todorovich 2007b; Montgomery 2011; Pain 2011a). In 2005, former RPA President Robert Yaro and Armando Carbonell, of the Lincoln Institute of Land Policy, went so far as to speak of an "American Spatial Development Perspective" emulating that in Europe that, according to Andreas Faludi, "turned into" the “America 2050” exercise (Armando and Yaro 2005; Faludi 2010, xii).

But the Polynet research introduced to policy debate in Europe and the U.S., especially at RPA/Lincoln Institute meetings in Vienna and Healdsburg, provides evidence demonstrating that this is by no means a given (Halbert, Pain, and Thierstein 2006; Pain 2011a; Pain and Van Hamme 2014). This is overlooked by Harrison and Hoyler's claim that "there has been little or no debate asking if megaregions are internally coherent spaces," Schafran being "one notable exception" (p. 10). Combining virtual and physical (commuting and business) flow with business network and institutional and policy analyses in the Polynet research produced a deeper understanding of regional globalisation as functionally differentiated and geographically uneven in all Northwest European PUR cases studied. But this only serves to endorse the "compelling" megaregions case for coordination and infrastructure development investments that seems to be questioned by Harrison and Hoyler at the start of the book (pp. 14--15). 
Undoubtedly, the distinctive contribution of the Megaregions volume is the light that it sheds on the dual construction of the megaregion, academically and politically. This is further exemplified by the PAR-LON and US megaregional construction processes discussed in this article. Despite the best intentions of leading megaregional actors, experience suggests that communicative meanings, intentions and interpretations can get dangerously mixed and confused in the megaregions construction maze.

U.S. research following in the wake of Ross (2009) for example, continues to seek to demonstrate how megaregion geography can aid business synergies, as in the case of e-retail developments, freight distribution, routing cost-efficiencies, and the like. Implicit in this agenda is the notion that business and commercial decision making should respond to new geographical realities, whereas a city-networks approach to analysis demonstrates that business and commercial decisions, in practice, play a critical part in the generation of spatial realities. Clearly, the theoretical framing of urban processes and of their research has profound political significance as Harrison and Hoyler are anxious to demonstrate. 
In concluding the volume, Harrison and Hoyler develop this point further in an attempt to answer the question whether the megaregion really is globalization's new urban form. They see the megaregions orthodoxy as principally opposed by analysis that prioritizes localized "spaces of the megaregion" (p. 245). But a city-networks research approach shows that social, economic, and material realities that are functionally interconnecting spaces at diverse scales are both locally and globally constructed and experienced (Cochrane and Pain 2000). The process of "the extension and intensification of global city functional relations ... beyond metropolitan boundaries" (interscale "megaregional spaces") must therefore remain a critical area for in-depth investigation, as must the issue of what are "appropriate forms of institutional structure, planning and governance arrangements and democratic engagement" (Harrison and Pain 2012, 1). Ultimately, Harrison and Hoyler strongly advocate combining "macro-" and “micro-level" analysis (p. 245). This means that to megaregions "can't-do" voices that need to be heard, the (generally underattended to) voices of policy and practitioner actors, genuinely perplexed by the challenges that networked urbanisation and geographic exigencies present, must be added.

Fleming's call for more research, as opposed to just critical commentary, is apposite. Megaregions provides a series of thought-provoking and question-prompting interjections to inspire 
and prompt new research agendas exploring these evolving interscale urban spaces and their complex communicative contexts.

\section{$<<$ A-HEAD $>>$ REFERENCES}

Brenner, N. 1998a. Between Fixity and Motion: Accumulation, Territorial Organization and the Historical Geography of Spatial Scales. Environment and Planning D: Society and Space 16 (4): $459-81$.

1998b. Global Cities, Glocal States: Global City

Formation and State Territorial Restructuring in Contemporary Europe. Review of International Political Economy 5 (1): 1-37. 1999. Globalisation as Reterritorialisation: The Rescaling of Urban Governance in the European Union. Urban Studies 36 (3): 431-51. 2004. New State Spaces: Urban Governance and the

Rescaling of Statehood. Oxford: Oxford University Press. 2009. Open Questions on State Rescaling. Cambridge Journal of Regions, Economy and Society 39 (2): 123-39. 
Brenner, N.1. and N. Theodore. 2002. Cities and the Geography of “Actually Existing Neoliberalism”. In Spaces of Neoliberalism: Urban Restructuring in North America and Europe, edited by N. Brenner, and N. Theodore, 349-379. Oxford: Wiley.

Carbonell, A. and R.D. Yaro. 2005. American Spatial Development and the New Megalopolis. Land Lines 17 (2): 1-4.

Castells, M. (1996). The Rise of the Network Society: The Information Age: Economy, Society and Culture, Volume I. Oxford UK: Blackwell.

Cochrane, A. and K. Pain. 2000. A Globalising Society? In $A$ Globalising World? Culture, Economics, Politics, edited by D. Held, 5-45. London: Routledge.

Faludi, A, ed, 2002. European Spatial Planning, Cambridge MA: Lincoln Institute of Land Policy. 2010. Cohesion, Coherence, Cooperation: European Spatial Planning Coming of Age? London: Routledge.

Florida R., Gulden T. and C. Mellande. 2008. The Rise of the Megaregion. Cambridge Journal of Regions, Economy and Society $1(3): 459-76$. 
Gravier, J.F. 1947. Paris et le Désert Français. Paris: Le Portulan.

Hagler, Y. 2009. Defining US Megaregions, America 2050. New

York: Regional Plan Association.

http://www.america2050.org/upload/2010/09/2050_Defining_US

Megaregions.pdf

Halbert, L. 2006. The Polycentric City Region That Never Was:

The Paris Agglomeration, Bassin Parisien and Spatial Planning

Strategies in France. Built Environment 32 (2): 184-193.

Halbert, L., Pain, K. and A. Thierstein. 2006. European

Polycentricity and Emerging Mega-City Regions - 'One Size Fits

All' Policy? Built Environment 32 (2): 206-218.

Halbert, L., Pain, K. and P.J. Taylor. 2007. Services Globaux,

Géographies Locales: Les Services Avances aux Entreprises á

Paris et Londres. French Speaking Regional Science Association

Annual Meeting 2007. Grenoble France: Association de Science

Regionale de Langue Francaise.

Halbert, L. and K. Pain. 2009. PAR-LON: Doing Business in Knowledge-Based Services in Paris and London: A Tale of One City? Globalization and World Cities (GaWC) Research Network 
Bulletin 307. Loughborough: Globalization and World Cities

Research Network. http://www.lboro.ac.uk/gawc/rb/rb307.html

2010. Services Globaux, Géographies Locales: Les

Services aux Entreprises dans les Métropoles de Londres et Paris.

Cybergeo: European Journal of Geography [En ligne], Espace,

Société, Territoire 510. http://cybergeo.revues.org/23337510

Hall, P. and K. Pain, eds. 2006. The Polycentric Metropolis:

Learning from Mega-City Regions in Europe. London: Earthscan.

Harrison, J. and K. Pain, eds. 2012. Global Cities, Volume IV:

Planning and Governance of Cities in Globalization. London:

Routledge.

Lambregts, B. 2006. Polycentricity: Boon or Barrier to

Metropolitan Competitiveness? The Case of the Randstad Holland.

Built Environment 32 (2): 114-123.

Lang, R.E. and D. Dhavale. 2005a. America's Megapolitan Areas, Land Lines 17 (3): 1-4.

2005b. Beyond Megalopolis: Exploring America's

New 'Megapolitan' Geography. Metropolitan Institute Census

Report Series 05:01, May 2005. Alexandria VA: Metropolitan 
Institute at Virginia Tech.

http://america2050.org/pdf/beyondmegalopolislang.pdf

Lang, R.E. and P.J. Taylor. 2005. U.S. Cities in the 'World City Network. Metropolitan Policy Program, Washington DC: The Brookings Institution.

Lang, R.E. and A.C. Nelson. 2007. America 2040: The Rise of the Megapolitans. Planning Magazine of the American Planning Association $6^{\text {th }}$ January.

2009. Megapolitan America: Defining and Applying a

New Geography. In Megaregions: Planning for Global

Competitiveness, edited by C.L. Ross, 107-126. Washington DC:

Island Press

Lincoln Institute of Land Policy, Regional Plan Association and University of Pennsylvania School of Design. 2004. Toward an American Spatial Development Perspective. Briefing Book for a Policy Roundtable on the Federal Role in Metropolitan

Development. New York: Regional Plan Association.

Mehlbye, P. 2000. Global Integration Zones - Neighbouring Metropolitan Regions in Metropolitan Clusters. Informationen zur Raumentwicklung 11/12: 755-762. 
Montgomery, C, ed. 2011. Regional Planning for a Sustainable America: How Creative Programs are Promoting Prosperity and Saving the Environment. Piscataway NJ: Rutgers University Press. Ohmae, K. 1995. The End of the Nation State: The Rise of Regional Economies. London: Harper Collins.

Pain, K. 2009. Londres: The Place to Be. Sciences Humaines, Les Grands Dossiers, 17: 30-32. 2010. The Emerging Metacity in North Western Europe and Policy Ramifications for Sustainable Transport Networks. In The Emerging Cross-border Mega-city region and Sustainable Transportation KOTI-EWC 2010 Special Report, edited by C. Mo, Y.H. Kim, 2-27, Hawaii / Korea: East-West Center / The Korea Transport Institute. 2011a. 'New Worlds' for 'Old'? Twenty-First-Century

Century Gateways and Corridors: Reflections on a European Spatial Perspective, International Journal of Urban \& Regional Research 35 (6): 1154-74.

2011b. Les Macro-Regions en Europe: Ile-de-France, Espace Fluides. In Proceedings Séminaire Européen - Quelles 
Perspectives pour les Métropoles en Europe? Un Regard Croisé sur l'Ile-de-France, 33-38. Paris: IAU-IDF (Institut d'aménagement et d'urbanisme de la région Ile de France) / Ile de France Europe.

2015a. World City. In The International Encyclopedia of Geography: People, the Earth, Environment, and Technology: Economic Geography and Regional Development, edited by D. Richardson, N. Castree, M.F. Goodchild, A.L. Kobayashi, W. Liu and R. Marston, forthcoming. Chichester: The Association of American Geographers / John Wiley \& Sons.

2015b. The Strategic Planning Protagonist: Unveiling the Global Mega-city Region. In Sir Peter Hall-Pioneers in Regional Planning, Transport and Urban Geography, edited by R. Knowles and C. Rozenblatt. International Geographical Union (IGU) Commission on Transport and Geography and International Geographical Union (IGU) Urban Commission, forthcoming. New York: Springer.

Pain, K. and P. Hall 2008. Informational Quantity Versus Informational Quality: The Perils of Navigating the Space of Flows. Regional Studies 42 (8): 1065-1077. 
Pain, K. and G. Van Hamme, eds. 2014. Changing Urban and Regional Relations in a Globalizing World: Europe as a Global Macro-Region. Cheltenham: Edward Elgar.

Porter, M. 2001. Regions and the New Economics of Competition. In Global City-Regions; Trends, Theory, Policy, edited by A.J. Scott, 139-157. Oxford: Oxford University Press.

Pushkarev, B. 1969. The Atlantic Urban Seaboard: Development Issues and Strategies. Regional Plan News 90 September. New York: Regional Plan Association.

Regional Plan Association. 2006a. America 2050: A Prospectus. New York: Regional Plan Association. http://www.america2050.org/pdf/America2050prospectus.pdf 2006b. America 2050 To-wards a National Strategy for Prosperity, Equity and Sustainability. In Proceedings of the Second Annual Policy Roundtable on Mega-Regional 36 Development. Tarrytown NY: Regional Plan Association. 2008. America 2050: An Infrastructure Vision for 21st Century America. New York: Regional Plan Association. 
Ross, C, ed. 2009. Megaregions: Planning for Global

Competitiveness. Washington DC: Island Press.

Sassen, S. 2007. Megaregions: Benefits Beyond Sharing Trains and Parking Lots. In The Economic Geography of Megaregions, edited by K.S Goldfeld, 59-83. Princeton: Princeton University.

Scott, A.J. 2001. Globalization and the Rise of City- regions.

European Planning Studies 9 (7): 813-26.

Short, J.R. 2010. Liquid City: Megalopolis and the Contemporary

Northeast. Washington DC: RFF Press.

Taylor, P.J. 2004. World City Network: A Global Urban Analysis. London: Routledge.

Taylor, P.J. and R.E. Lang. 2004. US Cities in the World City Network, Center on Urban and Metropolitan Policy Survey Series, December. Washington DC: Brookings Institution.

Taylor, P. J., Evans, D. M. and K. Pain. 2006. Organisation of the Polycentric Metropolis: Corporate Structures and Networks. In The Polycentric Metropolis: Learning from Mega-City Regions in Europe, edited by P. Hall and K. Pain, 53--64. London: Earthscan. 
Taylor, P. J., and K. Pain, 2007. Polycentric Mega-City Regions: Exploratory Research from Western Europe. In The Healdsburg Research Seminar on Megaregions, edited by P. Todorovich, 59-67. Cambridge, Mass.: Regional Plan Association, Lincoln Institute of Land Policy.

Todorovich, P., ed. 2007a. The Healdsburg Research Seminar on Megaregions. Cambridge, Mass.: Regional Plan Association, Lincoln Institute of Land Policy. 2007b. Introduction. The Economic Geography of Megaregions, edited by K.S Goldfeld, 3--10. Princeton, N.J.: Princeton University.

2011. Megaregion Planning and High-Speed Rail. In Regional Planning for a Sustainable America: How Creative Programs are Promoting Prosperity and Saving the Environment, edited by C. Montgomery, 261--267. Piscataway, N.J.: Rutgers University Press.

Dr. Pain is chair of real estate development at the University of Reading, Reading, RG6 6UD, U.K.; [http://www.henley.reading.ac.uk/people/person/professor-kathypain]. 